\title{
Implementing grammar materials during English classes
}

\author{
Fattoeva Nozigul Hudoyqul qizi ${ }^{1}$ \\ ${ }^{1}$ Student, Samarkand state institute of foreign languages, Uzbekistan \\ Email:fnozigul98@gmail.com
}

\begin{abstract}
Teaching grammar has been regarded as crucial to the ability to use language. Grammar skills will help learners to organize words and messages and make them meaningful. Knowing more about grammar will enable learners to build better sentences in speaking and writing performances.For this reason, this article introduces different ways in integrating grammar into the English classes. For example, grammar can be taught in listening, speaking, writing, and reading classes interactively and interestingly, it will be easier for students to acquire knowledge about grammar.
\end{abstract}

Keywords: Grammar, reading, writing, listening, speaking, listening hunts, stories, communicative language teaching, grammatical rules, English lessons.

\section{INTRODUCTION}

One of the most heated topics in the field of language teaching has been the role of grammar so the ways of teaching it have varied significantly. During the time of the more traditional methods, the focus was clearly on form and accuracy, and learning a language basically meant learning its grammar. After some time, people questioned the importance of grammar when the aim of language teaching changed more towards enhancing learners' communicational skills: "it was even suggested that teaching grammar was not only unhelpful but might actually be detrimental". Nowadays the general idea is that grammar really has its place in language learning and teaching, and research has demonstrated that focusing only on meaning is inadequate, hence one would not reach the highest level of competence without some focus on form Keck and Kim point out that for many years now, researchers' focus has been on "how to draw students' attention to grammar while come to a conclusion about the ideal balance between these two. Nassaji and Fotos state that "The controversy has always been whether grammar should be taught explicitly through a formal presentation of grammatical rules or implicitly through natural exposure to meaningful language use. But anyway grammar rules can help learners develop the habit of thinking logically and clearly in target language. That is why, implementing grammar rules, exercises or topics are one of the vital key factor of learning a target language. This research intended to find the importance of grammar teaching and ways to implement grammar materials into lessons.

\section{MAIN PART}

It is generally accepted that there are four language skills: Speaking, Listening, Reading and Writing. Grammar and vocabulary are not language skills. They are language components which are essential to the mastery of all the four skills. You cannot use any language skill without using grammar and vocabulary. In this case, every qualified teacher should implement grammar materials into their lessons whether it is reading, writing, speaking or other classes. For example, grammar can be modelled and practised aurally through the activities in listening classes. Like in listening hunts the teacher reads a short narrative and the students are asked to spot and write down as many instances as possible of the target structure(s) contained in the text. I usually tell the students in advance the number of occurrences of the target items in order to enhance their focus. 


\section{Figure 5- Listening hunt}

\section{Listen and note down as many irregular simple past tense form as you can spot in the text below}

Yesterday I went to the town centre with my girlfriend. It was hot and stuffy. We shopped for about an hour in one of the shopping malls in Bukit Bintang. Everything was so expensive! Afterwards, we had a bite at a Chinese restaurant. I am not usually fond of Chinese food, but I must admit that we had a great meal. The food was tasty and varied. I drank a bit too much beer, though, so I felt a bit drunk. We then decided to go and watch a movie. I had wanted to watch the latest James Bond movie for a while, so when I saw that it was still on I suggested we watch that. My girlfriend had not seen that movie either, so she went along with the idea. We both enjoyed the movie. It was packed with action and I loved the ending. After watching the movie we took a taxi back to the hotel. We were both shuttered.

Another way to improve your grammar is to read more in English. The more you read, the more you improve your grammar and vocabulary. In addition, everyone loves a story. Stories can be used for both eliciting and illustrating grammar points. The former employs inductive reasoning, while the latter requires deductive thought, and it is useful to include both approaches in lesson planning. In addition, a well-told story is the perfect context for a structure-discourse match, but the technique can also be used effectively for a structure-social factor match. Storytelling is one of these extremely versatile techniques, and once you get the hang of it, it can be a convenient and natural grammar teaching tool. You may even find that it is the technique that holds students' attention best, as well as the one they enjoy most. Grammar points can be contexualized in stories that are absorbing and just plain fun if they are selected with the interest of the class in mind, are told with a high degree of energy, and involve the students.

Speaking or conversation is also good way to teach grammar. And this approach tested by many foreign teachers. For example, Mrs Chakrakodi teaches English in a secondary school. Many of her students have problems with grammar structures that she thinks they should know by now. For instance, her students had problems using the imperative in a textbook exercise. She decided to try something which would help them to remember and use it." I noticed that Maggi noodles carry quick and simple recipes that even teenagers can try at home. I decided to use recipes to teach my students the imperative. One day I asked my Class IX students to bring empty Masala Maggi wrappers to the class. Before talking about making Maggi, I started a conversation about what they could cook, and whether they knew how to make tea. We had a whole-class discussion and I elicited from them the steps to make tea, which I put on the board. There were sentences like 'We boil water', 'I put in sugar', 'I put in milk', 'I add one spoon of milk power', etc. Amid a lot of laughter, we argued about whether to put sugar in the cup first, or tea leaves in the water itself, and I finally wrote the steps on the board, making a point to use imperative sentences ('Pour a cup of water in a kettle and boil ...', 'Add a spoonful of sugar ...'). Without my students necessarily realising it, I was reviewing the use of the imperative and its structure. I pointed out that the first word of each sentence was a verb, and that these sentences give instructions. With the students ready to use the structure, I divided them into groups and asked them to look at the recipes on the Maggi wrappers that they had brought from home. Their task was to discuss all the recipes, and to make a new and more interesting one using tips from all of them, using the imperative. As the students worked I walked around the groups, helping where necessary. After fifteen minutes, I started taking feedback. I asked a student from one of the groups to read out their recipe, which I wrote down on the board. We then discussed the recipe together, trying to add or change details where necessary. We also corrected any mistakes with the imperative."

Communicative language teaching (CLT) emphasizes learning a language first and foremost for the purpose of communicating with others. It emphasizes student-centered learning and face-to-face speaking activities, which provide learners with the information they need (i.e., a text, a game, pictures, demonstrations, etc.) to construct grammatical rules from instances and examples of language use .

Another best grammar instruction includes extensive reading and writing. This includes the teacher reading aloud to students of all ages. When students hear and see what is proper, they incorporate it into their own writing. This means that teachers need to provide extensive opportunities for students to 
read and write in the classroom. The writing process itself teaches grammar. As students proofread, edit and revise their own work, they learn about the proper use of grammar.

\section{CONCLUSION}

Grammar instruction holds an important place in foreign language learning. It needs to be noted that grammar skills will make great contribution to language competence. Grammar is an essential aspect to communicate effectively. Moreover, grammar simply is creating well-organized reading and writing performances. As it stated above, grammar is the base of every language. That is why, teaching grammar shoul be put on the first place of every language teacher. In our modern society there are many different ways of inserting grammar materials into English classes. It gives both teacher and student opportunity to teach and learn grammar interactively, effectively and easily.

\section{REFERENCES}

1. The Internet TESL Journal. Teaching Grammar in an ESL/EFL Setting. [consultation:19/09/04], 2004

2. OUP Teachers' Club. Individual Freedom in Languge Teaching. [in line] file: // A: Teachers' Club Articles. Fluency. [consultation:04/05/03]

3. Teachers' theories in grammar teaching. ELT Journal Volume 53/3 July 1999. OUP.

4. Self-perception and practice in teaching grammar. ELT Journal Volume 55/1 January.OUP.

5. Carter,R and Mc.Carthy M. (1995). Grammar and the Spoken Language. Applied Linguistics. Vol.16. No.2. OUP.

6. Davies, P and Pearse, E. (2002) OUP Teachers' Club. Success in English Teaching. A: teachers' Club. Success in English Teaching. htm. [consultation: 19/09/04].

7. Leech G and Svartvik J. (1989). A Communicative Grammar of English. Pueblo y Educación Editorial. Havana City.

8. Harmer, Jeremy, The Practice of Language Teaching, UK: Longman Handbooks for Language, Teachers, 1987

9. Harmer, Jeremy, How to teach English, UK: Longman Group, 1997

10. Thornbury, Scott, How to Teach Grammar, Longman, 1999

11. Vizental, Adriana, Metodica predării limbii engleze, Editura Polirom, 2008 